\title{
Selenium in Water Management Wetlands in the Semi-arid West
}

\author{
Dean A. Martens ${ }^{1}$ and Donald L. Suarez ${ }^{2}$ \\ USDA-ARS, United States Salinity Laboratory, Riverside, CA 92507
}

The geologic setting and climate of the west-central San Joaquin Valley of California has resulted in soil salinization. Agricultural engineering solutions to natural salinity problems sometimes have themselves created problems with respect to disposal of highly saline irrigation drainage return waters. A major problem with disposal of return waters from the west-central San Joaquin Valley of California is the inadvertent cycling and concentration of the trace element selenium (Se) in evaporation pond sediments. Selenium contamination of wetlands serving as drainage water evaporation ponds situated next to the Kesterson National Wildlife Refuge, Merced County, Calif., killed or impaired reproduction in wild, aquatic birds (Ohlendorf and Santolo, 1994). Experiments evaluating the toxicity of a range of naturally occurring Se compounds demonstrated that the $S$ amino acid analog selenomethionine (SeMet) is the most toxic to waterfowl (Heinz et al., 1987, 1988, 1989). Organic Se results from the assimilation of inorganic Se by microorganisms present in aquatic ponds and subsequent synthesis of organic compounds in which Se replaces S (Maiers and Knight, 1993).

Selenium is generally recognized as an essential micronutrient for growth and survival of mammals, birds, fish, algae and many bacteria (Burau, 1985; Stadtman, 1979). Recommended dietary Se concentrations range from 0.1 to $0.3 \mathrm{mg} \cdot \mathrm{kg}^{-1}$, whereas levels from 2 to $10 \mathrm{mg} \cdot \mathrm{kg}^{-1}$ can be toxic (Scott, 1973). Selenium toxicity results from the alteration of three-dimensional structure of proteins and the impairment of enzymatic function by substitution of Se for $\mathrm{S}$ amino acids (Frost and Lish, 1975). The structure of these proteins is a function of the sequence of amino acids and the location of disulfide bonding of the cysteine residues (Stryer, 1981). Substitution of Se for S in the amino acid analog selenocysteine (SeCys) alters protein structure because of pK differences between the sulfhydryl and selenol bridges.

As Se-containing microorganisms die and decompose, the organic Se compounds synthesized from inorganic Se may be released back into the environment. Plants also assimilate large amounts of Se into organic Se compounds (Shrift, 1973), but little is known as to the fate and distribution of this Se upon decomposition of the plant residues. Incorporation of Se may pose a problem of plant residue disposal where seleniferous waters are utilized for horticultural industries. Release of Se from such residues may contribute to increased organic Se concentrations found in evaporation pond ecosystems contaminated with inorganic selenate. As much as $60 \%$ of the total dissolved $\mathrm{Se}$ in aquatic systems may be present in organic forms (Cooke and Bruland, 1987; Takayanagi and Wong, 1985)

The purpose of this work was to investigate Se assimilation into a model plant, alfalfa (Medicago sativa L.), and then follow the distribution of Se and Se-amino acids before and after decomposition of plant tissue.

\section{MATERIALS AND METHODS}

Reagents. Stock solutions $\left(1000 \mathrm{mg} \cdot \mathrm{L}^{-1}\right)$ of Se $(+\mathrm{IV}$ and $+\mathrm{VI})$ were prepared, using $\mathrm{Na}_{2} \mathrm{SeO}_{3}$ and $\mathrm{Na}_{2} \mathrm{SeO}_{4}$ (Aldrich Chemical Co., St. Louis) in deionized (DI) water. Lower concentrations were prepared by serial dilution of stocks using DI water. Baker (J.T. Baker, Buffalo

Received for publication 4 Feb. 1998. Accepted for publication 4 Feb. Trade names and company names are included for the benefit of the reader and do not imply any endorsement or preferential treatment of the product listed by the U.S. Dept. of Agriculture, 1998. The cost of publishing this paper was defrayed in part by the payment of page charges. Under postal regulations, this paper therefore must be hereby marked advertisement solely to indicate this fact. ${ }^{1}$ Soil Scientist, USDA-ARS National Soil Tilth Laboratory, Ames, IA 50011. ${ }^{2}$ Research Leader.
Grove, Ill.) instra-analyzed grade $\mathrm{HCl}, \mathrm{HF}$, and $\mathrm{HNO}_{3}$ were used for all specified analyses. The $\mathrm{NaBH}_{4}$ and $\mathrm{K}_{2} \mathrm{~S}_{2} \mathrm{O}_{8}$ were used as received from Aldrich and the $\mathrm{K}_{2} \mathrm{HPO}_{4}$ and $\mathrm{KH}_{2} \mathrm{PO}_{4}$ were obtained from Baker. The amino acids were purchased from Sigma (Sigma Chemical Co., St. Louis), except for Se-methyl-selenomethionine (M-SeMet) and Se-methylselenocysteine (M-SeCys), which were synthesized using the methods of Toennies and Kolb (1945) and Foster and Ganther (1984), respectively.

Soil used (0 to $15 \mathrm{~cm}$ depth) was collected from the Panoche Fan in the west-central San Joaquin Valley, Calif. It represented a Panoche (Typic Torriothent) series and had the following chemical characteristics: $\mathrm{pH}, 8.06$; organic C, $5.6 \mathrm{~g} \cdot \mathrm{kg}^{-1}$; total $\mathrm{N}, 1.19 \mathrm{~g} \cdot \mathrm{kg}^{-1}$; and total Se, $0.1 \mathrm{mg} \cdot \mathrm{kg}^{-1}$, respectively. Particle size distribution was sand, $320 \mathrm{~g} \cdot \mathrm{kg}^{-1}$ of soil; and clay, $360 \mathrm{~g} \cdot \mathrm{kg}^{-1}$ of soil. Soil $\mathrm{pH}$ was determined on a 2.5 water : 1 soil ratio, total $\mathrm{C}$ content by dry combustion with a Coulometric $\mathrm{C}$ analyzer (UIC, Joliet, Ill.), total N content by the method described by Bremner and Mulvaney (1982), and texture by the hydrometer method of Gee and Bauder (1986). Total Se content was determined by placing the prepared soil material $(0.20-0.50 \mathrm{~g})$ in a 100 - $\mathrm{mL}$ PTFE (Teflon) beaker with $5 \mathrm{~mL}$ aqua regia $\left(3 \mathrm{HCl}: 1 \mathrm{HNO}_{3}\right)$ and $2 \mathrm{~mL} \mathrm{HF}$, covering with a watch glass and heating at $110^{\circ} \mathrm{C}$ in a sand bath for $2 \mathrm{~h}$ (Nham and Brodie, 1989). The Se content and location sampled made it likely that the soil microbial populations had been previously exposed to seleniferous plant residues.

Seleniferous alfalfa was produced in sand culture tanks irrigated every $5 \mathrm{~h}$ with 0.5 м Hoagland's solution (Hoagland and Arnon, 1950) or with a $0.5 \mathrm{~m}$ Hoagland's solution containing Se at $2 \mathrm{mg} \cdot \mathrm{L}^{-1}$ as sodium selenate. The alfalfa was harvested at the $1 / 10$ bloom stage and used as fresh material in the alfalfa decomposition experiments.

Apparatus. Hydride generation atomic absorption spectrophotometry (HGAAS) measurements were made with a Perkin Elmer 3030B spectrophotometer (Perkin-Elmer Corp., Norwalk, Conn.) equipped with a Varian model VGA-76 (Mulgrave, Victoria, Australia) vapor generation apparatus for Se analysis. A Se electrodeless discharge lamp (Perkin-Elmer) operated at $6 \mathrm{~W}$ was used as the radiation source. Operational conditions were as follows: acetylene flow, $2.4 \mathrm{~L} \cdot \mathrm{min}^{-1}$; air flow, $6.0 \mathrm{~L} \cdot \mathrm{min}^{-1}$; purge gas flow, argon, $90 \mathrm{~mL} \cdot \mathrm{min}^{-1}$; sample flow, $1.0 \mathrm{~mL} \cdot \mathrm{min}^{-1} ; 6 \mathrm{M} \mathrm{HCl}$ flow, $1.0 \mathrm{~mL} \cdot \mathrm{min}^{-1}$; reagent flow, $0.6 \% \mathrm{NaBH}_{4}$ $-0.5 \% \mathrm{NaOH}, 0.33 \mathrm{~mL} \cdot \mathrm{min}^{-1}$; wavelength, $196 \mathrm{~nm}$; and slit width, 2.0 $\mathrm{nm}$. A quality assurance procedure for Se analysis by HGAAS was employed as described by Martens and Suarez (1997a). All glassware was cleaned with detergent, rinsed, soaked overnight in $0.5 \mathrm{M} \mathrm{HNO}_{3}$, rinsed six times with DI water $\left(<10^{-5} \mathrm{dS} \cdot \mathrm{m}^{-1}\right)$, and air-dried prior to use.

Amino acid concentrations in the tissue before and after decomposition were determined as described by Martens and Frankenberger (1992). Briefly, the extracted amino acids were separated using a Dionex (Dionex Corp., Sunnyvale, Calif.) gradient pump (220-mL injection loop) by high-performance ion-exchange (HPIC) chromatography, utilizing a sodium hydroxide, sodium borate, and sodium acetate gradient on an AminoPac PA1 column (Dionex). Amino acids were detected using a Dionex pulsed amperometric detector (PAD) equipped with a gold electrode. Peak areas and retention times were determined with the Dionex AutoIon 450 software package. Our preliminary experiments showed that coelution of Met with SeMet or of SeCys with Cys was not a problem with this methodology. However, tyrosine coeluted with SeCys.

Alfalfa decomposition. A $25 \mathrm{~g}$ (FM) sample of alfalfa was added to a 500-mL Erlenmeyer flask and moistened with $15 \mathrm{~mL}$ of a Panoche soil extract as a source of soil microorganisms. The soil extract was obtained by shaking $100 \mathrm{~g}$ air-dry Panoche soil with $100 \mathrm{~mL}$ DI water for $1 \mathrm{~h}$ and centrifuging $\left(5000 \mathrm{~g}_{\mathrm{n}} ; 20 \mathrm{~min}\right)$ to obtain a soil-free supernatant. The flask was then attached to the apparatus train (Fig. 1) 


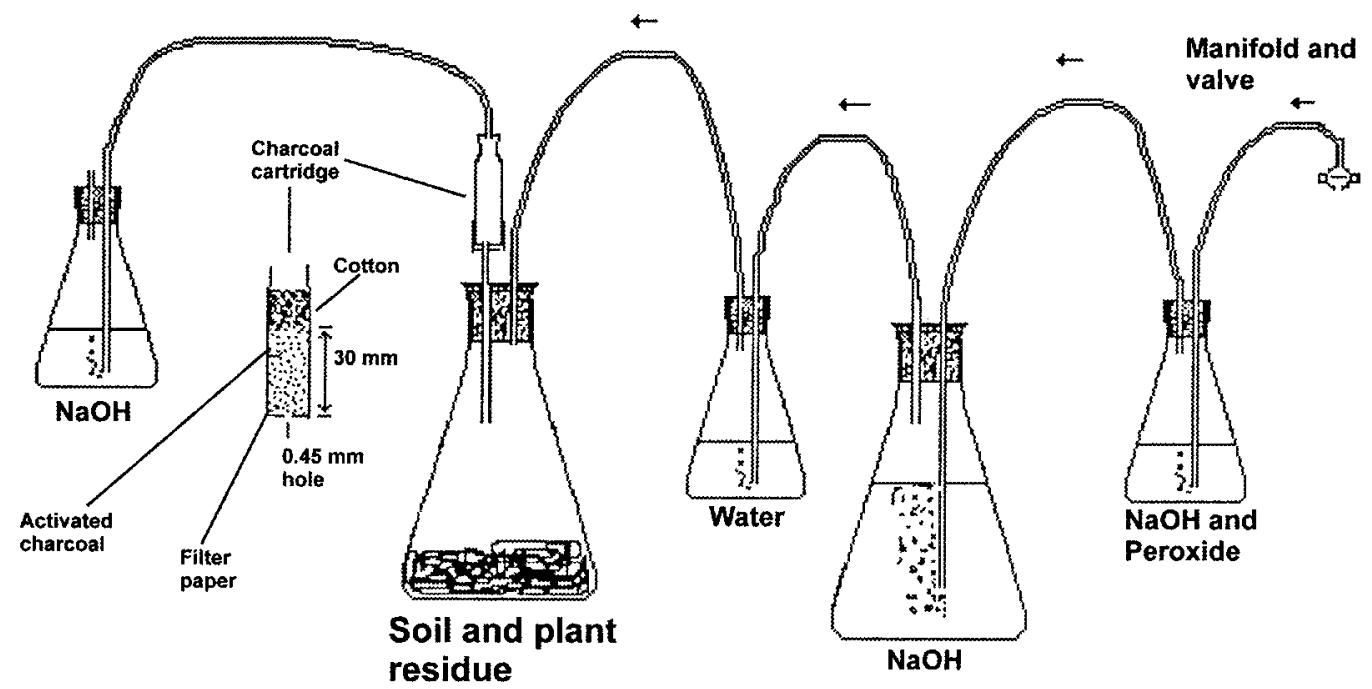

Fig. 1. Apparatus used to capture gases evolved during the aerobic alfalfa mineralization studies.

for collection of the evolved Se gas(es) and respired $\mathrm{CO}_{2}$, and aerobically incubated at ambient temperatures $\left(25 \pm 1^{\circ} \mathrm{C}\right)$ for $60 \mathrm{~d}$. Compressed air was passed through a $6 \% \mathrm{H}_{2} \mathrm{O}_{2}(\mathrm{pH} 9.0)$ solution, then through a $0.5 \mathrm{M} \mathrm{NaOH}$ solution, and finally through DI water (Fig. 1). A sample flow-rate of $10 \mathrm{~mL} \cdot \mathrm{min}^{-1}$ was maintained at each $500-\mathrm{mL}$ flask in the experiment via individual needle valves; this flow rate was chosen to effectively aerate the 500-mL flasks for collection of $\mathrm{CO}_{2}$ and volatile $\mathrm{Se}$ and $\mathrm{S}$ gases. The $\mathrm{CO}_{2}$ evolution was determined by back titration $(0.25 \mathrm{M} \mathrm{HCl})$ of a trap containing $0.5 \mathrm{M} \mathrm{NaOH}(10 \mathrm{~mL})$ treated with excess $\mathrm{BaCl}_{2}$ (Hassink, 1994). Exposed rubber surfaces were treated with Fluoroglide Teflon spray (Aldrich) to limit surface exposure of evolved gases. Evolved Se gases were trapped on a charcoal cartridge, which was then emptied into a $40-\mathrm{mL}$ centrifuge tube. The Se present was extracted with $10 \mathrm{~mL}$ of a $\mathrm{H}_{2} \mathrm{O}_{2}-\mathrm{HNO}_{3}$ solution $\left(30 \% \mathrm{H}_{2} \mathrm{O}_{2}, 80 \mathrm{~mL} \cdot \mathrm{L}^{-1} ; 17 \mathrm{M} \mathrm{HNO}_{3}, 58.8 \mathrm{~mL} \cdot \mathrm{L}^{-1}\right)$ and incubated at room temperature for $1 \mathrm{~h}$. The samples were then centrifuged $\left(10,000 g_{\mathrm{n}} ; 20 \mathrm{~min}\right)$ and the supernatant removed for analysis by reduction with $6 \mathrm{M} \mathrm{HCl}$ and HGAAS. After $60 \mathrm{~d}$, the flasks, three per sample, were disconnected from the apparatus train and allowed to air-dry $\left(25^{\circ} \mathrm{C}\right)$ before each sample was removed and homogenized with an agate mortar and pestle for Se and amino acid analysis.

Selenium extraction and speciation. Alfalfa was digested by modification of the $\mathrm{HNO}_{3}$ digestion method described by Banuelos and Pflaum (1990). Briefly, $17 \mathrm{M} \mathrm{HNO}_{3}(0.5$ to $1.0 \mathrm{~mL})$ was added to the plant material $(10-200 \mathrm{mg})$ in a $25-\mathrm{mL}$ graduated glass test tube, which was covered and the reaction allowed to proceed overnight, then the mixture was slowly heated on a sandbath to $130^{\circ} \mathrm{C}$ until brown fumes no longer were evolved $(3 \mathrm{~h})$. The sample was then treated with $1 \mathrm{~mL} 30 \% \mathrm{H}_{2} \mathrm{O}_{2}\left(130{ }^{\circ} \mathrm{C}\right)$ and $1 \mathrm{~h}$ later with $1 \mathrm{~mL} 0.1 \mathrm{M} \mathrm{K}_{2} \mathrm{~S}_{2} \mathrm{O}_{8}$ for 30 min $\left(130^{\circ} \mathrm{C}\right)$. After cooling, $0.5 \mathrm{~mL}$ saturated $\mathrm{NH}_{2} \mathrm{OH}-\mathrm{HCl}$ solution was added dropwise to reduce excess $\mathrm{HNO}_{3}$. The samples were then reduced with $6 \mathrm{M} \mathrm{HCl}$ until bubbling ceased. Samples were analyzed for Se by HGAAS.

To determine the distribution of Se oxidation states present in the seleniferous alfalfa before and after mineralization, $200 \mathrm{mg}$ alfalfa was placed into a 40-mL PTFE centrifuge tube and exposed to a sequential extraction scheme composed of a buffered phosphate (P-buffer) solution, a potassium persulfate $\left(\mathrm{K}_{2} \mathrm{~S}_{2} \mathrm{O}_{8}\right)$ solution, and a nitric acid $\left(\mathrm{HNO}_{3}\right)$ extraction (Martens and Suarez, 1997a).

A methanol : chloroform : water (M:Ch:W) extraction was performed to separate soluble, polar Se compounds present from the insoluble components. Before and after mineralization, alfalfa tissue (200 mg) was added to 40-mL centrifuge tubes and extracted with 15 $\mathrm{mL} 15 \mathrm{M}: 5 \mathrm{Ch}: 3 \mathrm{~W}$ (by volume) overnight with gentle shaking (60 oscillations/min). The samples were centrifuged $\left(3000 g_{\mathrm{n}}, 10 \mathrm{~min}\right)$ to pellet the residue and the supernatant was collected. The pelleted material was set aside to dry, and then digested for Se content by the method previously described for total plant Se. To separate the polar

\section{A} Se distribution in Alfalfa

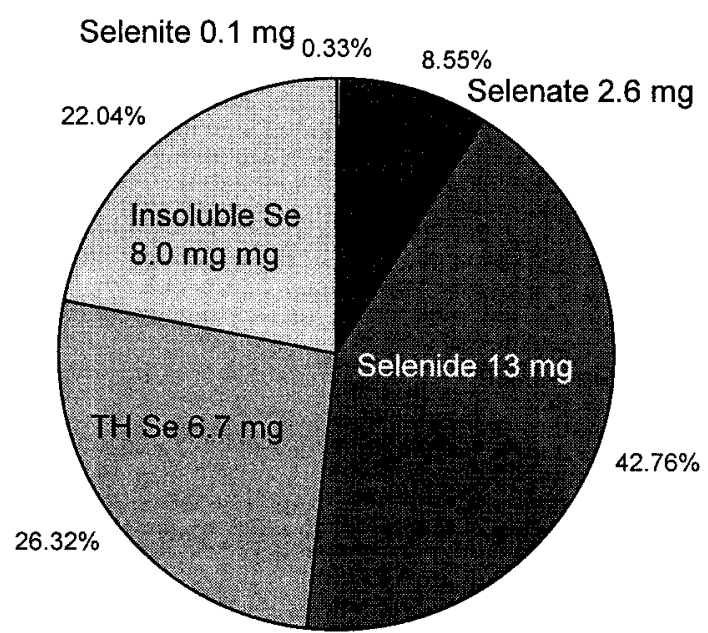

B

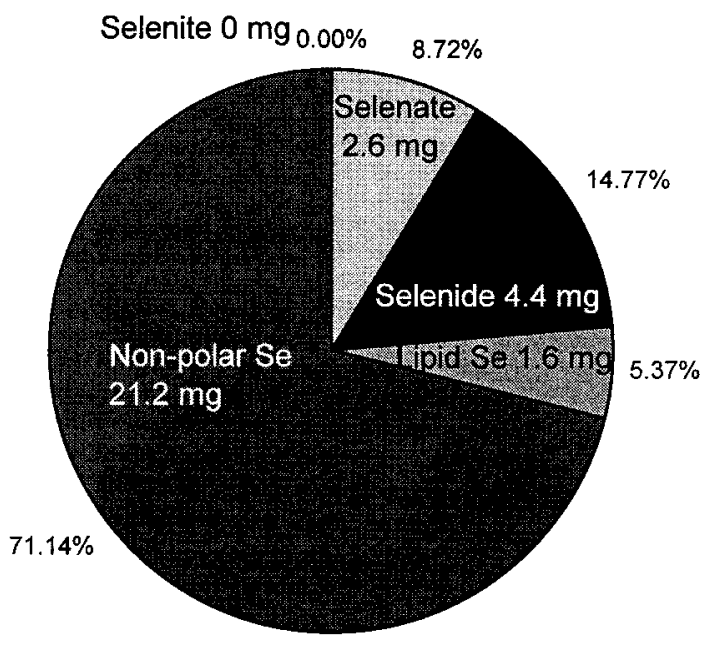

Fig. 2. Distribution of assimilated alfalfa Se as determined by (A) sequential extractions and HGAAS speciation analysis (total Se extracted $=30.4$ $\mathrm{mg} \cdot \mathrm{kg}^{-1}$ ) and (B) methanol : chloroform : water extraction and HGAAS speciation analysis (total Se extracted $=28.8 \mathrm{mg} \cdot \mathrm{kg}^{-1}$ ). 

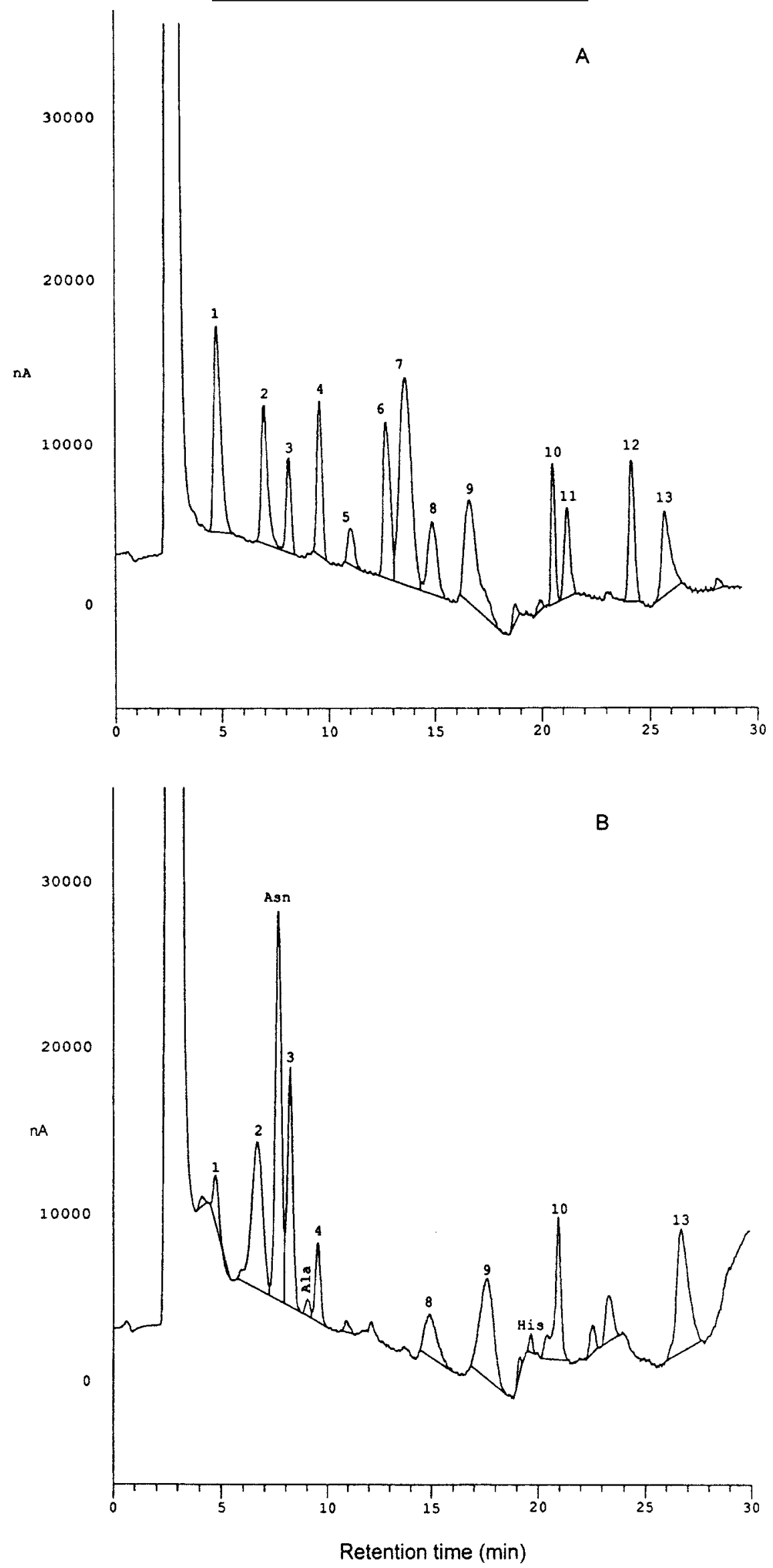

Fig. 3. Chromatographic traces of (A) amino acid standards and (B) amino acids present in the acidic ethanol extract $(0.1 \mathrm{M} \mathrm{HCl} ; 10 \% \mathrm{ethanol}, \mathrm{v} / \mathrm{v})$ of alfalfa before mineralization, separated by anion exchange chromatography and detected with pulsed amperometry (nA, nanaAmps). 1. Lys; 2. Gln; 3. Thr; 4. Ser and Val; 5. Pro; 6. M-Cys; 7. Met; 8. M-SeCys; 9. SeMet; 10. Phe; 11. Cystathionine; 12. Cys; 13. SeCys. 
compounds ( $\mathrm{M}: \mathrm{W}$ phase) from the lipids, pigments and the phenolic compounds (Ch phase), $6 \mathrm{~mL}$ DI water was added and the tubes were shaken for $10 \mathrm{~min}$. The samples were then centrifuged $\left(10,000 g_{\mathrm{n}}, 5\right.$ $\mathrm{min}$ ) to break the emulsion, and the pigmented $\mathrm{Ch}$ phase was removed, dried, and digested as previously described for total plant Se. The M:W phase was heated $\left(60^{\circ} \mathrm{C}\right)$ to remove the methanol and then the volume was adjusted to $10 \mathrm{~mL}$ total volume. Distribution of the Se oxidation states in the M:W phase was determined as described by Martens and Suarez (1997a).

Free Se-amino acids present in the alfalfa cytoplasm and cellular components were determined by placing $40 \mathrm{mg}$ alfalfa tissue (DM) in a tissue macerater $\left(4^{\circ} \mathrm{C}\right)$ and extracting with $5 \mathrm{~mL} 0.1 \mathrm{M} \mathrm{HCl}(10 \%$ ethanol v/v). The solution was filtered (pore size $0.1 \mathrm{~mm}$ ) and passed through a polyvinylpyrrolidone (Sigma) packed column $(1 \mathrm{~g})$ to remove possible interferences. An aliquot of the final solution was diluted for anion exchange separation with PAD analysis.

\section{RESULTS AND DISCUSSION}

The alfalfa produced in the selenate-spiked 0.5-M Hoagland's nutrient solution and harvested at the $1 / 10$ bloom stage of growth had an organic $\mathrm{C}$ content of $402.4 \mathrm{~g} \cdot \mathrm{kg}^{-1}$, a total $\mathrm{N}$ content of $55.6 \mathrm{~g} \cdot \mathrm{kg}^{-1}$, and a total Se content of $28.4 \mathrm{mg} \cdot \mathrm{kg}^{-1}$ alfalfa on a dry mass basis, resulting in a $\mathrm{C}: \mathrm{N}$ ratio of 7.24 and a $\mathrm{C}$ :Se ratio of 13,400 . Analysis of total Se content on all cuttings showed that the alfalfa variety used in this experiment never accumulated more than $30 \mathrm{mg} \cdot \mathrm{kg}^{-1}$, DM basis. Sequential extraction analyses determined that $50 \%$ of the Se assimilated was present in the P-buffer extract (Fig. 2A). The alfalfa assimilated $2.6 \pm 0.31 \mathrm{mg}$ selenate, $13.0 \pm 0.60 \mathrm{mg}$ selenide, and a trace of selenite as P-buffer extractable Se per kilogram. Rapid incorporation of selenate into organic Se compounds was evidenced by the low levels of inorganic selenite and selenate (8.6\% to 8.7\%) (Fig. 2). The soluble nature of phosphate-extractable Se suggests that the Se was present in the cytoplasm and cellular components of the tissue (Michaud and Asselin, 1995). The remaining Se appeared to be incorporated into insoluble proteins and cell walls, as stronger oxidation steps were needed to recover the $\mathrm{TH} \mathrm{Se}(8.0 \pm 0.58 \mathrm{mg} \mathrm{Se})$ and acid-soluble Se (6.7 $\pm 0.37 \mathrm{mg} \mathrm{Se})$ (Fig. 2).

Only $20 \%$ of the assimilated Se was present in the free polar fraction ( $4.4 \pm 0.10 \mathrm{mg}$ selenide; $1.6 \pm 0.08 \mathrm{mg}$ selenate) that is soluble in the methanol phase of the M:Ch:W extract. Lower levels of Se were detected in the chloroform phase $(1.6 \pm 0.05 \mathrm{mg} \mathrm{Se})$ as lipid, phenolic, or pigment Se. (Fig. 2B). Nonpolar, insoluble Se $(21.2 \pm 1.03 \mathrm{mg})$ accounted for the largest percentage of alfalfa Se. The low levels of soluble inorganic Se present in both the P-buffer and the M:Ch:W extracts suggests that leaching of Se from plant residues will not significantly increase soluble Se concentrations in soil.

Chromatography of amino acid standards determined that coelution did not occur between the amino acids Met and SeMet and Cys, SeCys, and M-SeCys (Fig. 3A). Anion exchange chromatography of the 0.1 M HCl-ethanol extract indicated the presence of the organic Se compounds SeMet, SeCys, and M-SeCys (Fig. 3B). The large peak for ethanol near the beginning of the chromatogram could have masked the presence of the Se compound M-SeMet. Fractionation, digestion, and HGAAS analysis of the suspected Se amino acid peaks confirmed the seleniferous nature of the amino acids and showed that low levels of M-SeMet were indeed masked by the ethanol peak. Of the Se content determined in the captured amino acid fractions, $75 \%$ was present as SeCys or M-SeCys. The free Se amino acids accounted for $77.3 \%$ of the total Se in the acidic ethanol extraction. Abrams and Burau (1989) detected trace levels of SeMet in soil samples from the San Joaquin Valley, Calif., using GC-MS, suggesting that low levels of the seleniferous amino acids can persist in soil. Other researchers have also detected Se amino acids in plant samples; Yasumoto et al. (1989) identified SeMet in the protein of soybean and Cai et al. (1995) detected SeCys, M-SeCys, and SeMet in $0.1 \mathrm{M} \mathrm{HCl}$ extracts of seleniferous and nonseleniferous onion and garlic.

Mineralization of the alfalfa Se was conducted by addition of a suspension of soil organisms to the tissue. Analysis of the respired C and volatilized Se showed that the majority of the $\mathrm{C}$ and Se lost from the system occurred during the first several weeks of incubation, with

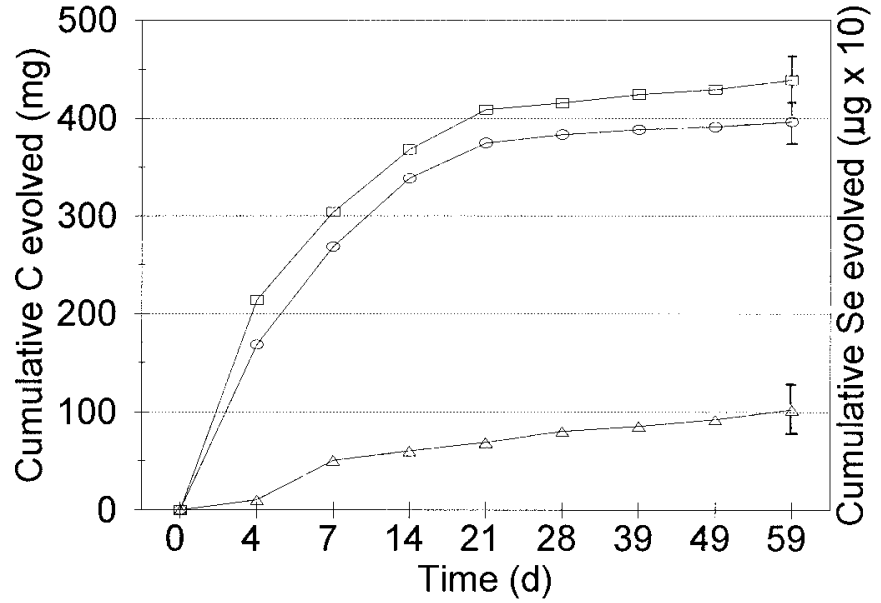

+ Control $\odot$ Se alfalfa $\therefore$ Volatile Se

Fig. 4. Cumulative $\mathrm{CO}_{2}$ and volatile Se released from alfalfa mineralization by soil microorganisms during $60 \mathrm{~d}$ of incubation at $25 \pm 1{ }^{\circ} \mathrm{C}$.

a lower rate of $\mathrm{C}$ and $\mathrm{Se}$ recovery with incubation (Fig. 4). Cumulative Se volatilized did not exceed $10 \%$ of the total Se content present in the added seleniferous alfalfa, and perhaps reflected the low concentration of SeMet in the acidic-ethanol extracts (Fig. 4B). Martens and Suarez (1997b) found that most of SeMet added to the Panoche soil was lost as volatile Se, with low levels of persistent inorganic Se. In contrast, SeCys additions to the Panoche soil were rapidly mineralized to nonamino acid selenide-Se and then to inorganic Se with low levels of Se volatilization. These results suggest that the Se volatilized during the mineralization of seleniferous alfalfa determined here originated from SeMet.

The $\mathrm{CO}_{2}$ respiration rate showed that, initially, the Se-containing alfalfa was not mineralized as rapidly as the control alfalfa (Fig. 4). This lag appeared to coincide with the time period when the greatest amounts of volatile Se were released. After the rate of Se loss decreased, respiration rates for the seleniferous alfalfa were similar to those for the control rates for the remainder of the experiment (Fig. 4).

In biological samples, any or all of the four Se oxidation states, selenate, selenite, elemental Se, and selenide, may be present (Martens and Suarez, 1997c). The extraction procedures employed here also demonstrated that Se compounds in plants such as alfalfa vary greatly in solubility. After mineralization, both sequential (Fig. 5A) and M:Ch:W (Fig. 5B) extractions indicated a large Se enrichment in the remaining residue. Sequential extractions showed concentrations (mg.kg ${ }^{-1} \mathrm{DM} \pm$ standard deviation) of $13.1 \pm 1.2$ selenite, $13.6 \pm 1.35$ selenate, $24.8 \pm 2.15$ selenide, $11.9 \pm 1.02 \mathrm{TH}$ selenium, and $17.4 \pm$ 0.96 refractory Se for the mineralized residue. The C:Se ratio determined for the fresh alfalfa was 13,400. After microbial decomposition this ratio decreased to 3800 , indicating a 3.5 -fold increase in the Se concentration. The M:Ch:W extractions yielded (mg $\left.\cdot \mathrm{kg}^{-1} \mathrm{DM}\right) 6.02 \pm$ 2.8 selenite, $12.5 \pm 1.56$ selenate, $7.7 \pm 2.1$ selenide, $4.3 \pm 1.7$ lipid $\mathrm{Se}$, and $56.8 \pm 1.56$ insoluble Se after mineralization. After $60 \mathrm{~d}$ of mineralization the tissue was devoid of the extractable amino acids that were present initially. Only low levels of SeMet and Phe were identified in the extracts, indicating that most of the P-bufferextractable selenide-Se remaining in the mineralized residue was present as nonamino acid selenide (data not presented).

A total protein digestion (Martens and Frankenberger, 1992) of the mineralized alfalfa tissue remaining showed that about half of the total non-Se amino acids present before decomposition were still accounted for in the mineralized residue (data not presented, 1997). The data suggest that much of the initial loss of $\mathrm{C}$ and Se resulted from the mineralization of cytoplasmic and cellular components. The inorganic Se species, selenate and selenite, increased during incubation because of mineralization of insoluble Se fractions. The large decrease in the $\mathrm{C}$ :Se ratio after mineralization suggests that soil organisms mineralized nonseleniferous organics at a faster rate than seleniferous organic compounds. 

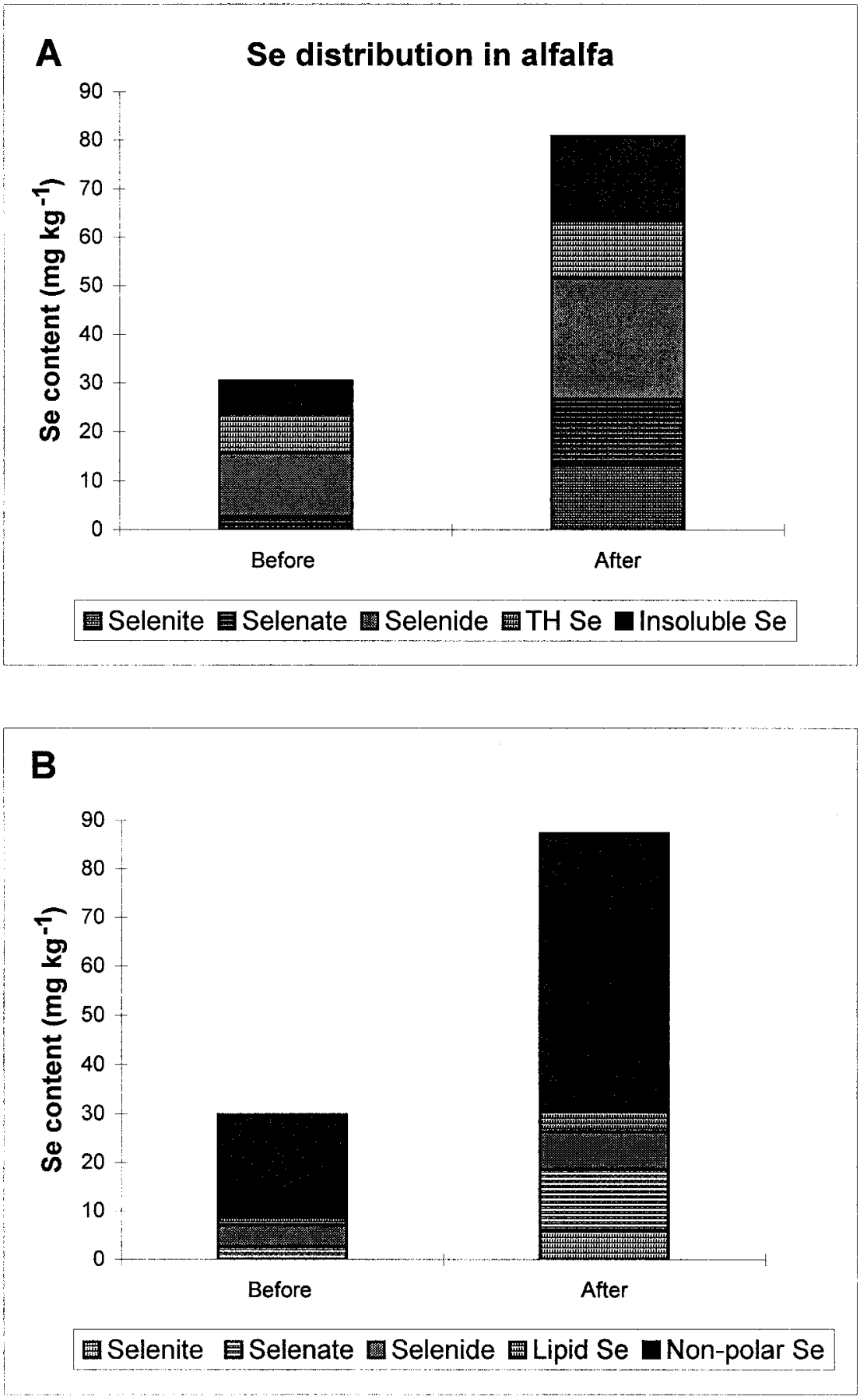

Fig. 5. Distribution of assimilated alfalfa Se before and after mineralization by soil microorganisms for $60 \mathrm{~d}$ as determined by (A) sequential extractions and HGAAS speciation analysis, and (B) M:C:W extraction and HGAAS speciation analysis.

This slower mineralization rate of Se-containing organic compounds may help explain why Se compounds can increase rapidly in the environment. Martens and Suarez (1997c), after evaluating a number of seleniferous soils and evaporation pond sediments from the San Joaquin Valley, suggested that the distribution of the Se oxidation states present in the evaporation ponds could be controlled by limiting organic $\mathrm{C}$ accumulation. Organic-associated Se present in evaporation pond soils increased rapidly when the organic $\mathrm{C}$ content increased above $20 \mathrm{~g} \cdot \mathrm{kg}^{-1}$. An aerated drainage water evaporation pond that limited plant growth (soil organic C, $4.6 \mathrm{~g} \cdot \mathrm{kg}^{-1}$ ) assimilated less organic-associated $\mathrm{Se}(18 \%)$ from irrigation drainage waters than did ponds with uncontrolled plant growth (soil organic C, $26.7 \mathrm{~g} \cdot \mathrm{kg}^{-1}$ soil), which had $>80 \%$ organic-associated Se. At present, no management plans are in place for dealing with seleniferous irrigation waste water, but our research suggests that vegetative management of evaporation ponds can affect the distribution of Se and also limit the formation of toxic Se compounds.

\section{Literature Cited}

Abrams, M.M. and R.G. Burau 1989. Fractionation of selenium and detection of selenomethionine in a soil extract. Commun. Soil Sci. Plant Anal. 20:221-237.

Banuelos, G.S. and T. Pflaum. 1990. Determining selenium in plant tissue with optimal digestion conditions. Commun. Soil Sci. Plant Anal. 21:17171726.

Bremner, J.M. and C.M. Mulvaney. 1982. Nitrogen-Total, p. 595-624. In: A.L. Page, R.H. Miller, and D.R. Keeney (eds.). Methods of soil analysis, part 2, 2nd ed., vol. 9. Amer. Soc. Agron., Madison, Wis.

Burau, R.G. 1985. Environmental chemistry of selenium. Calif. Agr. 39:16-18. 
Cai, X.J., E. Block, P.C. Uden, X. Zhang, B.D. Quimby, and J.J. Sullivan. 1995. Allium chemistry: Identification of selenoamino acids in ordinary and selenium-enriched garlic, onion, and broccoli using gas chromatography with atomic emission detection. J. Agr. Food Chem. 43:1754-1757.

Cooke, T.D. and K.W. Bruland. 1987. Aquatic chemistry of selenium: Evidence of biomethylation. Environ. Sci. Technol. 21:2114-2119.

Foster, S.J. and H.E. Ganther. 1984. Synthesis of $\left[{ }^{75} \mathrm{Se}\right]$ trimethylselenonium iodide from $\left[{ }^{75}\right.$ Se $]$ selenocystine. Anal. Biochem. 137:205-209.

Frost, D.V. and P.M. Lish. 1975. Selenium in biology. Annu. Rev. Pharmacol. $15: 259-284$

Gee, G.W. and J.W. Bauder. 1986. Particle-size analysis, p. 383-409. In: A. Klute (ed.). Methods of soil analysis, part 1, 2nd ed. vol. 9. Amer. Soc. Agron., Madison, Wis.

Hassink, J. 1994. Effects of soil texture and grassland management on soil organic $\mathrm{C}$ and $\mathrm{N}$ and rates of $\mathrm{C}$ and $\mathrm{N}$ mineralization. Soil Biol. Biochem. 26:1221-1231.

Heinz, G.H., D.J. Hoffman, and L.G. Gold. 1988. Toxicity of organic and inorganic selenium to mallard ducklings. Arch. Environ. Contam. Toxicol. 17:561-568

Heinz, G.H., D.J. Hoffman, and L.G. Gold. 1989. Impaired reproduction of mallards fed an organic form of selenium. J. Wildl. Mgf. 53:418-428.

Heinz, G.H., D.J. Hoffman, A.J. Krynitsky, and D.M.G. Weller. 1987. Reproduction in mallards fed selenium. Environ. Toxicol. Chem. 6:423-433.

Hoagland, D.R. and D.I. Arnon. 1950. The water culture method for growing plants without soil. College of Agr., Univ. of California, Berkeley. Circ. 347.

Maiers, K.J. and A.W. Knight. 1993. Comparative acute toxicity and bioconcentration of selenium by midge Chironomus decorus exposed to selenate, selenite, and seleno-DL-methionine. Arch. Environ. Contam. Toxicol. 25:365-370.

Martens, D.A. and W.T. Frankenberger, Jr.. 1992. Pulsed amperometric detection of amino acids separated by anion exchange chromatography. $\mathrm{J}$. Liq. Chromatog. 15:423-439.
Martens, D.A. and D.L. Suarez. 1997a. Selenium speciation of soil/sediment determined with sequential extractions and hydride generation atomic absorption spectrophotometry. Environ. Sci. Technol. 31:133139.

Martens, D.A. and D.L. Suarez. 1997b. Mineralization of selenium-containing amino acids in two California soils. Soil Sci. Soc. Amer. J. 61:1685-1694.

Martens, D.A. and D.L. Suarez. 1997c. Selenium speciation of marine shales, alluvial soils, and evaporation basin soils of California. J. Environ. Qual. 26:424-432.

Michaud, D. and A. Asselin. 1995. Application to plant proteins of gel electrophoretic methods. A review. J. Chromatog. 698:263-279.

Nham, T.T. and K.G. Brodie. 1989. Evaluation of digestion procedures for the determination of selenium in soil comparing vapour generation and graphite furnace atomic absorption spectrometry with Zeeman-effect background correction. J. Anal. Atomic Spectr. 4:697-700.

Ohlendorf, H.M. and G.M. Santolo. 1994. Kesterson reservoir-Past, present and future: An ecological risk assessment, p. 69-117. In: W.T. Frankenberger, Jr., and S.M. Benson (eds.). Selenium in the environment. Marcel Dekker, New York.

Scott, M.L. 1973. Selenium dilemma. J. Nutr. 103:803-808.

Shrift, A. 1973. Selenium compounds in nature and medicine, p. 763-814. In: D.L. Klayman and W.H.H. Gunther (eds.). Organic selenium compounds: Their chemistry and biology. Wiley, New York.

Stadtman, T.C. 1979. Some selenium-dependent biochemical processes. Adv. Enzymol. Relat. Areas Mol. Biol. 48:1-28.

Stryer, L. 1981. Biochemistry. p. 32. Freeman, San Francisco.

Takayanagi, K. and G.T.F. Wong. 1985. Dissolved inorganic and organic selenium in the Orca Basin. Geochim. Cosmochima. Acta 49:539-546.

Toennies, G. and J.J. Kolb. 1945. Methionine studies. VII. Sulfonium derivatives. J. Amer. Chem. Soc. 76:849-851.

Yasumoto, K., T. Suzuki, and M. Yoshida. 1988. Identification of selenomethionine in soybean protein. J. Agr. Food Chem. 46:463-467. 